\title{
哺乳動物の歯, とくに咬頭の形態発生について
}

\author{
酒 井 珧 朗 \\ 愛知学院大学歯学部 第 1 解剖学教室*
}

[受付 : 昭和 49 年 2 月 23 日]

\begin{abstract}
抄録 : 食中目の歯の比較解剖学的研究と，ヒトの歯のエナメル・象牙境についての形態学的研究の成果に 基づき, 哺乳動物の多くの咬頭の形態発生を次のように推測する。1) すでに形成されている歯冠歯频部に cingulum が作られる。2) cingulum の一部が咬頭側に向かって突隆し棘状の突起が作られる。この突起は しだいに大きくなり，その頂点は歯面自体から離れて独立する。3）独立した突起の頂点と歯面との間にほぼ 水平に走る幅の狭い鋭い隆線，すなわち “cingulum-cusp crest”が形成される。4) cingulum に続く棘状 の突起はさらに大きさを増すと，結節・咬頭状を呈するようになり， cingulum は本来の形態を失い結節・ 咬頭に転化する。この段階で，結節・咬頭と cingulum との関係は不明となる。5）以上のようにして cingulum が咬頭に転化した後，さらにこの咬頭の外側に第 2 の cingulum が作られ，この cingulum から前 述した発達段階を経て新しい咬頭が形成される。
\end{abstract}

\section{はじめに}

歯の系統発生に関する問題は，主として歯の形 態, とくに哺乳動物の臼歯に見られる多咬頭歯の 形態発生について論議されてきた。複雑な形をし た多咬頭歯は，単純なハプロドント haplodont の歯から進化したものであるということについて は，現在ほとんど異論はないが，その変化の過程 については多くの意見がある。多咬頭歯の系統発 生についての学説は, 融合説と分化説に 2 大別す ることができる。前者は数個のハプロドントまた は 3 錐歯 triconodont が癒合することにより複雑 な多咬頭歯が形成されると説き，後者はこれに反 してハプロドントが基礎となり，多数の副結節に 分化していくと説くものである。そして最近で は, 魚類, 両生類, 爬虫類等の下等脊椎動物の歯 が必ずしも定型的なハプロドントではなく，しば しば $2 \sim 3$ 咬頭歯であるという事実から，咬頭分 化の可能性 potential は脊椎動物において非常に 早くから存在していたと考えられている。分化説 では，系統発生ならびに個体発生において，歯の どの部分に何という咬頭が，何時頃どういう順序
で分化してきたか，したがってハプロドントの咬 頭が哺乳動物の複雑な臼歯のどの咬頭に相当する か, また中生代哺乳動物の臼歯が新生代哺乳動物 網各類にどのようにして受けつがれていったか等 をめぐって論議されてきた。これらの点について は, Vandebroek ${ }^{1)}$ (1967), Hershkovitz ${ }^{2)}$ (1971) 等の研究がある。さらに最近は化石資料の充実と 相まって，歯の形態との関連においてその咀嚼機 能を検討することにより，咬頭分化の歴史的過程 はかなり明らかにされてきた。この点については Crompton $^{3)}$ (1971), Kermack et al. ${ }^{4,5)}$ (1965, '68) Mills ${ }^{6,7)}(1966$, '67) 等の研究がある。

しかしながら，咬頭の分化そのものの機構につ いては不明の点が多い。Cope ${ }^{8)}$ (1874), Osborn ${ }^{9)}$ （1888）の 3 結節説では，新しく生ずる咬頭は歯冠 の一部が “budding or outgrowih”することに よると説明しているにすぎない。Allen ${ }^{10)}$ (1874), Tims (1896), Hrdlička ${ }^{11)}$ （1921）等の歯帯説に よると，咬頭発生の母地は歯帯 cingulum である という。また，井尻 ${ }^{12)}$ (1938) の Invaginationshypothese は, 哺乳動物網各類の歯牙形態発生 は 1 個の抽象的エナメル器の内・外エナメル上皮

\footnotetext{
Morphogenesis of the mammalian tooth, with special reference to the cusp.
}

Takuro SAKAI (Department of Anatomy, Aichi-Gakuin University, School of Dentistry, Nagoya)

* 名古屋市千種区末盛通り 2-11 (广 464) Jap. J. oral Biol., $16: 245-251,1974$. 
面の Invagination（面積の増加を伴った膨出・筋 入・褶曲・翻転等）により規定されていると主張 し, すべての歯の形を連続的，理論的かつ系統的 に説明している。

われわれは歯の系統発生の問題を再検討する意 図を持って, 食虫目, 霊長目等の歯の比較解剖学 的研究 (酒井, 花村 ${ }^{13,14}$ : :1967, 1969，1973) と, 日本人の歯のエナメル・ゾウゲ境についての形態 学的研究 (酒井・佐々木・花村 ${ }^{15-17)}: 1965, ' 67$, '69，'71，'73）を平行して行なってきた。それら の研究成果に基づき, 哺乳動物の歯, とくに咬頭 分化の機構について，筆者の意見を述べてみたい。

\section{I. 具体的事実}

哺乳動物多咬頭歯の形態発生に 関する著者の見 解の基礎となった 具体的事実は次の 4 項目に要約 できる。

1. 多くの結節・咬頭は歯帯 cingulum から作 られる。

現生人類の大臼歯を脱灰すると，上顎において hypocone, Carabelli 結節, 下顎において hypoconulid, protostylid 等は，その部に現われる明 らかな歯帯 cingulum とそれに続く棘状の突起と して出現し，咬頭ないし結節としての形態をほと んど失う。現生人類大臼歯のエナメル・象牙境に 見られるこれらの形態は，化石霊長類大臼歯のエ ナメル質表面に観察される形態ときわめて良く類 似している。例えば, Pliopithecus, Limnopithecus, Adapis 等の化石霊長類や Hylobates 等の現生霊 長類の 上顎大臼歯および第 4 小臼歯において, Hypocone は舌側 cingulum に連続し, その一部 が膨隆することによって作られたものであること を示している（図 1)。また, 現生人類下顎大臼歯 のエナメル・象牙境において, hypoconulid は煩 側 cingulum の遠心上昇部と続き，その突隆部と して示されている。下頻大臼歯における cingulum と hypoconulid との関係は, 図 2 に示すように, 上䫟大臼歯における舌側 cingulum と hypocone との関倸と本質的に同様である。なお Frisch ${ }^{18)}$ (1965) によると, Hylobates lar, Sivapithecus のカラベリー結節, Dryopithecus fontani の protostylid, Propliopithecus $の$ hypoconulid 等は明 らかに cingulum と続いており，その一部が膨隆

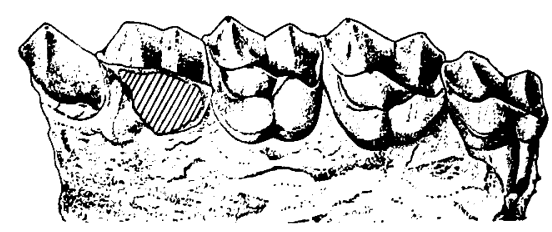

a

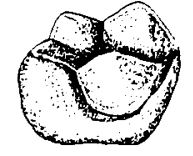

b

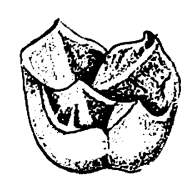

c
Fig. 1 Lingual cingulum and hypocone. a : Adapis magnus. Enamel surface of upper premolar and molar [KORENHOF]

$\mathrm{b}$ : Hylobates moloch leuciscus. Enamel surface of upper molar [FRISCH]

c : Recent man : Enamel-dentin border of upper molar [SAKAI]
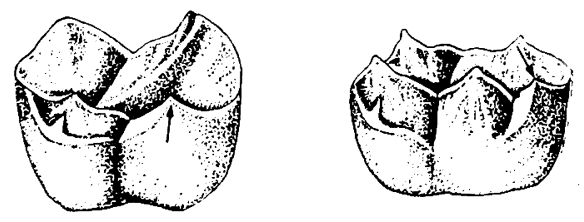

Fig. 2 Hypocone and hypoconulid on enamel-dentin border. Left : upper molar, lingual view. Right : lower molar, buccal view.
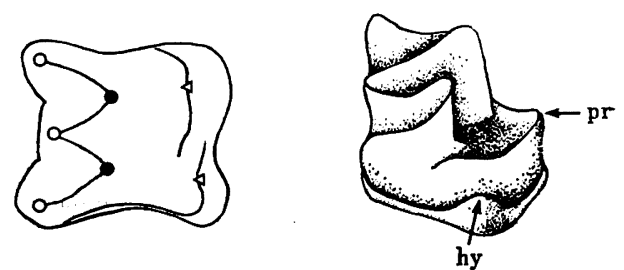

Fig. 3 Upper first molar of Sorex shinto, distal view. pr: protocone, hy : hy. pocone.

することによって作られたものであるということ である。また食虫目トガリネズミ科の第 4 小臼歯 と大臼歯に扔いても， hypocone は明らかに舌側 cingulum と連続し，その一部が膨隆することに より作られた咬頭であることを示している（図 3)。

多くの食虫目の第 4 小四歯および第 1 大臼歯に 

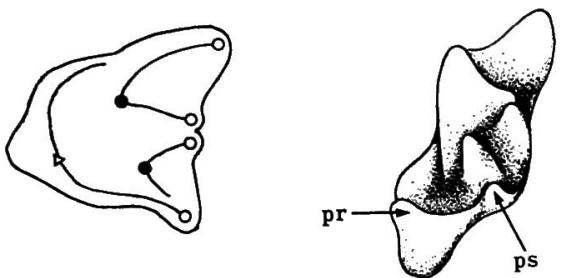

Fig. 4 Upper first molar of Euroscaptor mizura, mesial view. pr : protocone, ps : parastyle.

おいて, parastyle, metastyle, protocone, parastylid, distal cusp 等は cingulum に続いており, その一部が棘状に隆起することにより作られたも のである。例えば，図 4 はミズラモグラ上顎第 1 大臼歯の近心面観を示したものであり, parastyle は paracone の近心基底部に付着した小さな結節 状をなしこの歯の舌側を取り巻いている protocone を作った cingulum の近心煩側の末端部が 隆起して作られたものであることを示している。

Patterson $^{19 \prime}$ (1956) によると, 古白亜紀の真獣 類 (therian mammal of metatherian-eutherian grade) の上顎小臼歯では， parastyle を作った cingulum は, paracone の近心舌側斜面の基底部 のところで肥厚し, protocone を作っているとい うことである。

モグラ科の下顎第 4 小臼歯においては, protoconid の煩側面基底部付近から弱い cingulum が生じ遠心に延びて遠心面に達する。この cingulum はここでかなり発達の良い結節 distal cusp を作った後, 舌側面基底部をかこみ近心面に達し parastylid を作る。これを要するに，多くの結 節・咬頭は cingulum の一部が棘状に隆起するこ とによって作られたものであるということができ る。

2. cingulum に続く棘状の突起の 頂点から, すでに形成された歯面に向かって，ほぼ水平に経 過する幅の狭い鋭い隆線がしばしば出現する。

現生人類の大自歯のエナメル・象牙境において しばしば, hypocone, Carabelli 結節, hypoconulid あるいは protostylid に相当する棘状突起の頂点 から, それぞれ trigonal hypocone crest, cingulum-protocone crest, cingulum-hypoconid crest, cingulum-protoconid crest と呼ばれる明ら

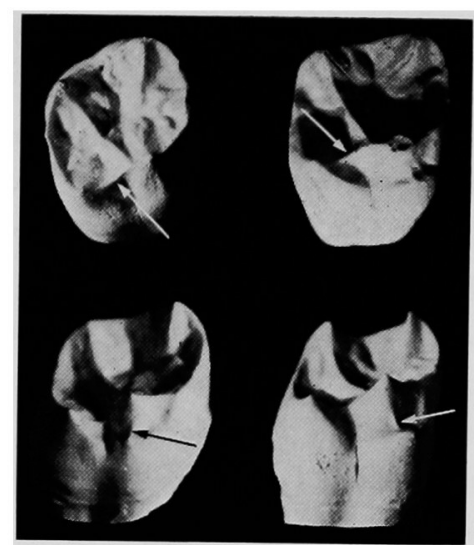

Fig. 5 Cingulum-cusp crest on enameldentin border of upper first molars [SAKAI]

Upper : trigonal hypocone crest, Lower : cingulum-protocone crest.
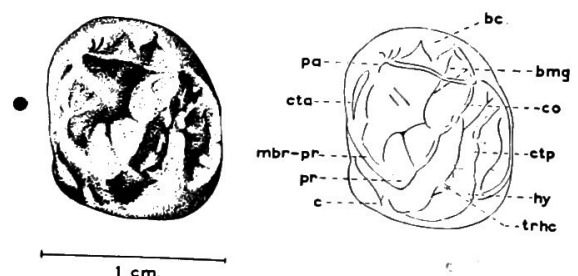

Fig. 6 Trigonal hypocone crest (trhc) of upper molar of Dryopithecus [KoRENHOF].

かな鋭い隆線が水平に走り，すでに形成された歯 面に達する。例えば，上䫑大臼歯のエナメル・象 牙境において舌側 cingulum から棘状の小さな突 起が $3 \sim 4$ 個咬合縁の方に突出していることがし ばしばある。ある例で, 突起のうちの一つが特に よく発達して, その頂点が舌側面自体から独立す るようになると, 棘状突起の頂点と protocone 舌 側面とを結ぶ鋭い隆線が作られる。これが cingulum-protocone crest (Korenhof $\left.{ }^{201} 1960\right)$ であり, カラベリー結節の形成と墚い関係がある(図 5 )。

エナメル・象牙境に観察されるこれらの crest は猿類臼歯のエナメル質表面においてもしばしば 観察される。例えば, Necrolemur, Pliopithecus, Dryopithecusに拉いては trigonal hypocone crest が, Pliopithecus, Dryopithecus, Hylobates 等に おいては cingulum-protocone crest が観察され る(図 6 )。

食虫目においては，モグラ科の上顎第 4 小臼歯 
と第 1 大臼歯の parastyle から鋭、隆線が paracone の近心斜面に向かって下降することがある。 また下顎第 4 小臼歯では，舌側 cingulum が近心 舌側隅角部において近心に張り出して parastylid と呼ぶ小結節を作るが，この結節の頂点から paraconid の近心面に向かい鋭い隆線が走っている。 オオアシトガリネズミの第 1 大臼歯の metaconule, ヒメヒミズの第 2 大臼歯の protoconule と metaconule から，それぞれ metacone あるいは paracone の基底部に向かい鋭い隆線が走る。こ れらの細い鋭い隆線はいずれも cingulum に続く 棘状の頂点から既に形成された咬頭斜面に向かっ て延びており, trigonal hypocone crest や cingulum-protocone crest と同じ性質のものであり， 一般に “cingulum-cusp crest” と総称すること ができる。

3. cingulum に続く棘状の 突起が，しだいに 大きくなり，結節・咬頭状にまで発達すると， cingulum との関倸は不明となる。

現生人類大臼歯のエナメル・象牙境に見られる cingulum は，エナメル質表面に拈ててほとん ど完全に消失する。しかし cingulum からの棘状 突起は逆にエナメル質表面において増大し明らか に結節・咬頭として観察される。したがって，エ ナメル質表面では結節・咬頭と cingulum との関 係は全く不明となる。例えば，上頷大臼歯舌側面 近心側に出現するカラベリー結節は多くの研究者 により cingulum に由来した形質であると考えら れている。現生人類大臼歯のエナメル質表面には 良く発達した結節がしばしば出現するが，cingulum は観察されないので, cingulum と結節との 関係は不明である。しかし，この結節を有する上

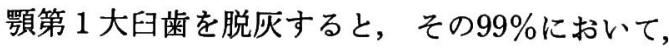
その部に cingulum が出現する。その cingulum から結節の位置に一致して棘状突起と cingulumprotocone crest が生じている。すなわち，エナ メル・象牙境では cingulum と結節との関係が明 らかに確認される。図 7 はカラベリー結節を持つ 上顎大臼歯の エナメル質表面とその歯のエナメ ル・象牙境とを比較したものである。

大多数の食虫目モグラ科の上顎第 4 小臼歯と第 1 大臼歯においては，前に述べたように，para-

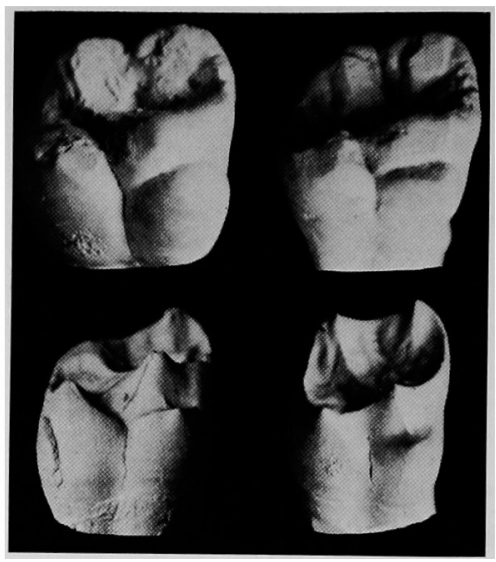

Fig. 7 Carabelli's cusp on enamel surface (upper) and lingual cingulum with spine on enamel-dentin border (lower) [SAKAI].

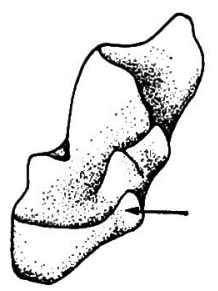

$\mathbf{M}^{1}$

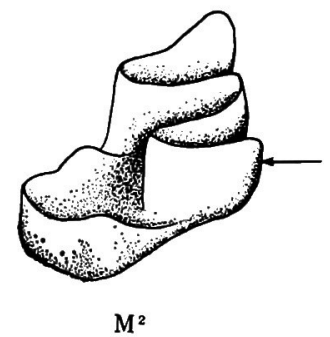

$M^{2}$
Fig. 8 Parastyle of Dymecodon pilirostris, mesial view.

style は舌側 cingulum と連続しており，その一 部が突隆することにより作られた咬頭であること は明らかである。しかし，アズマモグラの上頻第 1 大臼歯では parastyle が他のモグラよりもよく 発達し, 近心にかなり突隆し cingulum とは連続 していない。また，第 2 大臼歯および第 3 大臼歯 ではモグラ科 4 種を通じて parastyle は発達が顕 著で高く隆起し, cingulum とは完全に分離しお 互いの関係は不明である。図 8 はヒメヒミズの近 心面観であり，第 1 大臼歯と第 2 大臼歯との比較 を示した。

トガリネズミ科の上顎第 4 小臼歯において， ジ ネズミ亜科では parastyle は protocone を発達 させた cingulum に続き両者の関係は明らかであ るが, トガリネズミ亜科では parastyle の発達が 顕著で cingulum との関係は不明となる(図 9)。

4. 歯冠基底部には cingulum が 2 重に作られ 


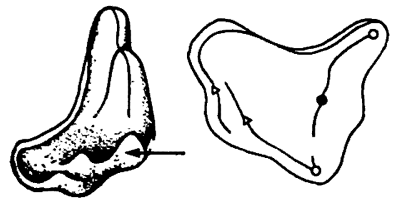

Crocidura dsinezumi

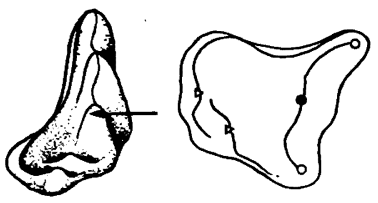

Sorex minutus

Fig. 9 Parastyle of upper fourth premolar, mesial view.
良好な protocone cingulum の舌側基底部を，そ れより発達の良くない hypocone cingulum が取 り囲んでおり，両者は溝によって分離されている。 なお, Pliopithecus, Epipliopithecus, Limnopithecus, Proconsul, Gorilla, Colobus 等では hypocone cingulum のさらに舌側に cingulum が 作られることがある。Zapfe und Hürzeler ${ }^{211}$ (1957) はそれを“Neocingulum”と呼んでい る。 Remane' ${ }^{22)}$ (1960) によると, この Neocingulum は 2 つの種類が区別されるということであ る。すなわち，その1つは protocone cingulum,
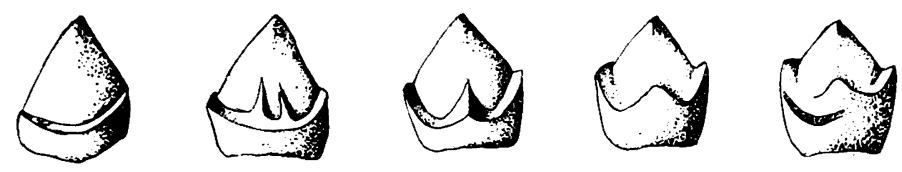

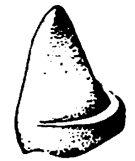

I

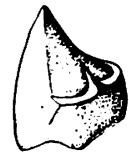

II

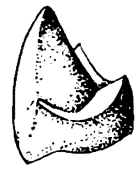

III

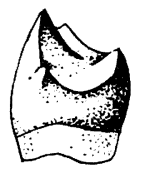

IV

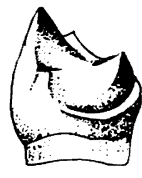

$\mathrm{V}$

Fig. 10 Structural stages in the morphogenesis of the tooth cusp (schematic).

I : Well-formed original cingulum

II : Cingulum with spines

III : Incipient cusp with cingulum-cusp crest

IV : Well-formed cusp

$\mathrm{V}:$ Secondary cingulum

ていることがある。

トガリネズミ科の 上顎第 4 小臼歯と大臼歯にお いては図 3 に示すように, protocone を作った cingulum の舌側にもう1つの cingulum が作ら れる。すなわち, protocone cingulum は一般に parastyle の基底部付近から生じ，paracone およ び metacone の舌側を取り巻いて metacone の 遠心側で自然に消失する。その経過中に cingulum の一部が隆起することによって protocone が作ら れる。この cingulum の舌側にあるもう1つの cingulum は metastyle の頂点から連続して歯冠 遠心面を廻り，遠心舌側線角部付近で hypocone を作った後, protocone の近心面あるいは舌側面 のところで自然に消失する。したがって, 発達の hypocone cingulum と同じ性質のもので第 3 の cingulum である。他の 1 つは hypocone の辺縁 隆線が舌側に拡大し, 後に hypocone から分離し て作られたものであると説明している。第 1 の場 合は上顎大臼歯の舌側に cingulum が 3 重に作ら れたことになる。

これを要するに, 第 1 の cingulum が咬頭形成 に使われ，その後また新しい cingulum がその咬 頭の外側に新生される。

\section{II. 咬頭の形態発生}

I 項に述べた具体的事実から，哺乳動物歯牙の 多くの咬頭の形態発生は次のような発達段階を経 過するものと考えられる(図10)。

1. すでに形成されている歯冠歯頸部に, cin- 
gulum が作られる。この cingulum の発達が良 好な場合には，歯面から階段状あるいは棚状に張 り出しており，その表面は平坦で凹凸は見られな い。

2. cingulum の一部が咬頭側に向かって突隆 し，小さな棘状の突起が 1 ～数個作られる。次い でこれらの突起のうち通常 1 個，まれに 2 個が他 の突起より大きくなり，その頂点が歯面自体から 離れて独立するようになる。

3. 独立した棘状突起の頂点と歯面との間に, ほぼ水平に走る幅の狭、鋭、隆線が形成され，両 者を橋渡しする。すなわち, trigonal hypocone crest, cingulum-protocone crest 等であり, これ らを総称して “ cingulum-cusp crest” と呼ぶこ とができる。

4. cingulum に続く棘状の突起はさらに大き さを増すにつれて，結節状または咬頭状を呈する ようになり， cingulum は本来の形態を失い結節 ないし咬頭に転化する。したがって，この段階に おいては，結節ないし咬頭と cingulum の関係は 不明となる。
5. 以上のようにして, cingulum が咬頭に転 化した後, さらにこの㕮頭の外側に新しく第 2 の cingulum が新生される。次いで前述の $1 \sim 4$ の 発達段階を経て新しい咬頭が形成される。

\section{おわりに}

筆者は，食虫目，霊長目等の歯の比較解剖学的 研究と, ヒトの歯のエナメル・象牙境についての 形態学的研究の結果に基づき，哺乳動物の歯，と くに咬頭の形態発生の諸段階を推測した。

さらに, cingulum から咬頭が形成される要因, 系統発生および個体発生における cingulum から の咬頭形成の時期，順序，法則等を具体的な対象 について検討したいと考えている。

この研究の基礎となった食虫目の多くの資料は，信州 大学医学部第 2 解剖学教室所藏のものであり, 貴重な資 料観察の機会を与えていただいた同教室宮尾獤雄先生に 厚く御礼申し上げます。

この論文の要旨は成長談話会第 5 回大会(新捣，1973) において発表した。

Summary: The author have reported on the crown characters of the Japanese dentition on the exterior suface of enamel and on the interior surface of dentinoenamel junction, and on the dentition of Insectivora. A tentative hypothesis of mammalian molar morphogenesis that took into account the results of these studies might be formulated as follows.

1. A basal extension (cingulum) develops from the cervical portion of the tooth crown.

2. Three or four spines start from the cingulum and rise in an occlusal direction, arid then one of the spines increases in size. As the spine continues to expand, its tip is separated from the surface itself.

3. A small sharp crest starts from the independent tip of the spine, and connects the spine with the slope of the crown. This crest is called "cingulum-cusp crest".

4. As the spine becomes more pronounced and assumes a cusp-like appearance, the anterior and posterior slopes of the cusp gradually confluent with cingulum, and thus the original cingulm is changed into the cusp.

5. The next change occurs a secondary basal extension on the outside of this cusp. The secondary extension (secondary cigulum) gives rise to a new cusp in the way described above.

\section{文献}

1) VANDEBROEK, G.: Origin of the cusps and crests of the tribosphenic molar. J. Dent. Res., 46 (suppl.): 796-804, 1967.

2) Hershkovitz, P.: Basic crown patterns and cusp homologies of mammalian teeth. Dental Morphology and Evolution (edited by Dahlberg, A. A.), p. 95-150, Univ. Chicago Press, Chicago. 1971.

3) Crompton, A. W.: The origin of the tribosphenic molar. Early Mammals (edited by 
Kermack, D. M. and Kermack, K. A.), p. 65-87, Linn. Soc. London, Acad. Press, London. 1971.

4) Kermack, K. A., Less, P. M. and Mussett, F.: Aegialodon dawsoni, a new tuberculosectorial tooth from the lower Wealden. Proc. R. Soc. (B), 162 : 535-554, 1965.

5) KERMACK, D. M., KERMACK, K. A. and MussetT, F.: The Welsh pantothere Kuehneotherium praecursoris. J. Linn. Soc. (Zool.), 47 : 407-423, 1968.

6) Mills, J. R. E. : The functional occlusion of the teeth of Insectivora. J. Linn. Soc. (Zool.), $47:$ 1-25, 1966.

7) Mills, J. R. E.: A comparison of the lateral jaw movements in some mammals from wear facets on the teeth. Archs Oral Biol., 12 : 645-661, 1967.

8) COPE, E. D. : On the homologies and origin of the types of molar teeth of Mammalia Educabilia. J. Acad. Nat. Sci., Phila., 2nd ser., 8 : 71-89, 1874.

9) OsBorn, H. F.: The evolution of mammalian molars to and from the triangular type. Amer. Naturalist, 22 : 1067-1079, 1888.

10) Allen, H.: The facial region: the nomenclature of the teeth. Dent. Cosmos, 16 : 617$623,1874$.

11) HRDLIČKA, A.: Further studies of tooth morphology. Amer. J. Phys. Anthrop., 4 : 141-176, 1921.

12) 井尻正二 : Desmostylus japonicus を中心とせ る哺乳動物歯牙形態発生理論に関する一考察 Invaginationshypothese. 地質誌，45:566-572, 1938.

13）酒井瑯, 花村 肇 : ツパイの歯の形態学的研 究. 第22回日本人類学会, 日本民族学会連合大 会, 名古屋, 1967 .
14）酒井瑯，花村 肇：食虫目の歯の形態学的研 究. I.トガリネズミ科. 愛学院大歯誌， 7 : 1-26, 1969.; II. モグラ科. 歯基礎誌， 15 : 333-346, 1973.

15）酒井秝朗, 佐々木泉, 花村 肇 : 日本人歯牙の エナメル・ゾウゲ境についての形態学的研究.

人類誌, $73: 91-109,1965 ; 75: 155-172,207-$ 223, $1967 ; 77: 71-98,1969 ; 79: 297-322$, $1971 ; 81$ : 25-45, 87-102, 1973.

16) SAKAI, T.: Morphologic study of the dentinoenamel junction of the mandibular first premolar. J. Dent. Res., 46 (suppl.) : 927-932, 1967.

17）酒井瓈朗：人類永久歯冠における諸形質の系統 発生学的意義. 愛学院大歯誌, 8: 133-149, 1971.

18) Frisch, J. E. : Trends in the evolution of the hominoid dentition. Bibl. Primatol., 3 : 1-130, S. Karger, Basel. 1965.

19) PAtTerson, B. : Early cretaceous mammals and the evolution of mammalian molar teeth. Fieldiana, Geology, 13 : 1-105, 1956.

20) KoRENHOF, C. A. W.: Morphogenetical aspects of the human upper molar. A comparative study of its enamel and dentine surfaces and their relationship to the crown pattern of fossil and recent primates. Uitgeversmaatschappij Neerlandia Utrecht, 1-368, 1960.

21) ZAPFE, H. und Hürzeler, J. : Die Fauna der miozänen Spaltenfüllung von Neudorf a. d. March. Primates Sitzungsber. Österr. Ak. Wissenschaft. Math. nat. Kl. Abt. I, Bd. 166 : 113-123, 1957.

22) Remane, A.: Zähne und Gebiss. Primatologia III, Teil 2, S. Karger, Basel, 637835, 1960. 